\title{
WÓDZ DOSKONAŁY W ŚWIETLE LACIŃSKICH PANEGIRYKÓW PÓŹNOANTYCZNYCH
}

\begin{abstract}
„Armia owiec, prowadzona przez lwa jest lepsza niż armia lwów, prowadzona przez owcę". Ta przypisywana Napoleonowi opinia zdaje się idealnie pasować do osądów społecznych również w okresie późnego antyku. W III i IV w. panowało przekonanie, że wobec licznych zagrożeń zewnętrznych i wewnętrznych państwo rzymskie nie może sobie pozwolić na komfort posiadania władcy, który byłby nieobeznany ze sztuką wojenną ${ }^{1}$. Niemal wszyscy panujący tego okresu prowadzili osobiście swoje wojsko do walki, choć trzeba przyznać, że skutek przez nich odnoszony był różny. Paradoksalnie, pomimo że w wieku V i VI stopień zagrożenia państwa nie zmalał, lecz jeszcze wzrósł, obecność cesarzy na polu bitwy przy boku swoich żołnierzy stała się czymś wyjątkowym, nawet jeżeli panujący posiadał zdolności dowódcze. Nie zmienia to faktu, że w dalszym ciągu jedną z najważniejszych cech każdego władcy, stanowiącą podstawowy element jego autoprezentacji, miała być skuteczność $\mathrm{w}$ walce $\mathrm{i}$ obronie cesarstwa przed wszelkimi zagrożeniami. Jeżeli cesarz samodzielnie nie uczestniczył w działaniach wojennych, należało przynajmniej stworzyć wrażenie, że tak w istocie było. Bardzo ważną funkcje w tym zakresie spełniali panegiryści. W swoich utworach kreowali oni obraz idealnego wodza, którego przymioty stawiane były na eksponowanym miejscu. Choć przełom wieku IV i V przyniósł w tej materii zasadniczą zmianę, a rolę władcy coraz częściej, zwłaszcza na Zachodzie, przejmowali wszechpotężni magistri militum, zadanie panegirysty pozostało niezmienne - w dalszym ciagu był on odpowiedzialny za budowanie wizerunku rządzących na różnorodnych, w tym również militarnej, płaszczyznach.

Niniejszy artykuł stanowić będzie analizę wizerunku wodza doskonałego w łacińskiej literaturze panegirycznej okresu późnej starożytności [XII Panegyrici Latini, Klaudiusz Klaudianus (ok. 370 - ok. 405), Sydoniusz Apolinary (ok. 430 - ok. 485), Merobaudes (V w.), Pryscjan (ok. 470 - ok. 530), Ennodiusz (ok. 475 - ok. 520), Korippus (ok. 500 - ok. 570)], na podstawie której
\end{abstract}

* Dr Adrian Szopa - asystent w Katedrze Historii Starożytnej w Instytucie Historii na Wydziale Humanistycznym Uniwersytetu Pedagogicznego im. Komisji Edukacji Narodowej w Krakowie; e-mail: aszopa@up.krakow.pl.

${ }^{1}$ Por. A.D. Lee, War in Late Antiquity. A social history, Malden - Oxford - Carlton 2007, 22-25. 
wyodrębnione zostaną te cechy, których w powszechnym odbiorze społecznym od niego oczekiwano ${ }^{2}$. Wskazane zostaną także środki jakie wykorzystywali twórcy panegiryków, aby stworzyć obraz idealnego dowódcy. Zwrócę również uwagę na to, jak w toku rozwoju tego gatunku literackiego zmieniało się podejście do kwestii przedstawienia władcy, jako idealnego wodza, by wreszcie odpowiedzieć na nieco przekorne pytanie: czy „wirtualny” głównodowodzący $\mathrm{z}$ łacińskich panegiryków miałby szansę wygrać jakiekolwiek starcie zbrojne? W tle wciąż będzie się pojawiać refleksja, czy analizując kwestie militarne możemy traktować panegiryk jako wiarygodne źródło historyczne.

1. Panegiryki lacińskie w późnym antyku. Już w republikańskim Rzymie podstawowym elementem edukacji wyższych warstw społeczeństwa były studia retoryczne. Właściwych zasad wymowy musiał nauczyć się każdy, kto pragnął spróbować swoich sił w karierze politycznej, podczas której publiczna deklamacja przed różnorodnym audytorium była czymś zwyczajnym. Ewolucja systemu rządów państwa rzymskiego doprowadziła do tego, że w interesującym nas okresie późnego antyku wymowa doradcza oraz sądowa ustąpiły miejsca popisowej ${ }^{3}$. Powiązany z nią rozwój ceremoniału dworskiego stworzył zapotrzebowanie na utwory, których celem było wychwalanie cnót i działań władcy lub innego ważnego dostojnika ${ }^{4}$. Funkcje te spełniały właśnie

${ }^{2}$ Pełne zestawienie zachowanych - w całości lub obszernych fragmentach - panegiryków łacińskich znajdzie czytelnik w: W. Portmann, Geschichte in der Spätantiken Panegyrik, Europäische Hochschulschriften: Reihe 3: Geschichte und ihre Hilfswissenschaften 363, Frankfurt am Main 1988, 319-321. Wraz z panegirykami w języku greckim dysponujemy łącznie prawie 60 panegirykami z okresu późnej starożytności.

3 Trójczłonowy, klasyczny i uznany powszechnie podział wymowy odnaleźć możemy już u Arystotelesa (Ars rhetorica I 3, 1358a 36 - 1358b 8, w: tenże, Opera, ed. I. Bekkerus, vol. 2, Berolini 1831, 1358, thum. H. Podbielski: Arystoteles, Retoryka, Warszawa 1988, 75-76). W okresie późnej starożytności nie stracił on nic ze swojej aktualności i pojawił się już na początku traktatu Menandra Retora (Menander Rhetor 331, w: tenże, Opera, edited with translation and commentary by D.A. Russell and N.G. Wilson, Oxford 1981, 2), o którym będzie jeszcze mowa w niniejszym artykule.

${ }^{4}$ Większość panegiryków, które są przedmiotem analizy w niniejszym artykule była pochwałą cesarzy. Niemała jednak ich liczba skomponowana została, aby wychwalać głównodowodzących armii. Szczególnie w V w. na Zachodzie ta tendencja była niezwykle silna, a najlepiej o tym świadczą utwory Klaudiana i Merobaudesa. Związane jest to z niezwykle mocną pozycją, jaką u boku swoich suzerenów posiadali Stylichon i Aecjusz. Wodzowie ci, obdarzani konsulatami, odbierali podobną cześć, co ich władcy, a ich możliwości polityczne, w pewnych okresach, były znacznie większe niż panujących. W takiej sytuacji pochwała, która była do nich skierowana w panegiryku, nie różniła się zanadto od tej, która poświęcona była cesarzom. Co więcej, nawet kiedy utwór poświęcony był władcy, wkomponowana była w niego pochwała naczelnego wodza. Zważywszy na to można uznać, że panegiryki cesarskie oraz te poświęcone głównodowodzącym (magistri militum) można potraktować jako utwory należące do tego samego gatunku, a prezentowany w nich wizerunek dowódcy analizować w ramach tych samych rozważań. Zdecydowanych cech dystynktywnych nie można znaleźć zbyt wielu. $Z$ oczywistych względów nikt inny poza cesarzem nie mógł być określany jako caesar lub imperator, jednak pozostałe środki wyrazu były niemal takie same. 
panegiryki, które wygłaszano podczas różnorodnych oficjalnych uroczystości takich np. jak intronizacja, czy też adventus ${ }^{5}$. Ich początków, jako gatunku literackiego, można doszukiwać się już w literaturze Grecji archaicznej ${ }^{6}$. $\mathrm{Na}$ gruncie rzymskim zbliżoną do nich rolę pełniły w okresie republikańskim laudationes funebres. Dla rozwoju gatunku niebagatelne znaczenie miały już niektóre mowy Cycerona (3 I 106 - 7 XII 43 prz. Chr.) oraz Seneki Młodszego (ok. 4 prz. Chr. - 65 po Chr.), ale pierwszy raz nazwa panegiryk została zastosowana dopiero wobec przemówienia Pliniusza Młodszego (ok. 61 - ok. 115) wygłoszonego przed senatem w roku $100^{7}$. Zawierało ono liczne elementy charakterystyczne dla późnorzymskich panegiryków i dlatego może być uznane za ich bezpośredniego poprzednika ${ }^{8}$. Nieprzypadkowo znalazło się ono w zbiorze XII Panegyrici Latini i to pomimo znacznego dystansu czasowego, który dzielił kompozycję Pliniusza od pozostałych elementów tego zestawienia9. Miało ono prawdopodobnie stanowić rodzaj podręcznika dla uczniów szkół retorycznych, a zawarte w nim utwory panegiryczne możemy,

${ }^{5}$ Por. S. MacCormack, Art and Ceremony in Late Antiquity, Berkeley - Los Angeles - London 1981, 1-14, gdzie autorka przedstawia w jakich okolicznościach wygłaszane były panegiryki. Pytanie czym tak naprawdę były te utwory stanowi przedmiot dyskusji wśród współczesnych badaczy. L.K. Born (Perfect Prince According to the Latin Panegyrist, „The American Journal of Philology” 55 (1934) nr 1, 20-35) uznawał je za tzw. specula principum, czyli „zwierciadła”, w których odbijały się oczekiwane od panującego cnoty. Inną opinię wyrażał J.A. Straub (Vom Herrscherideal in der Spätantike, Forschungen zur Kirchen- und Geistesgeschichte 18, Stuttgart 1939) uznając panegirystów za antycznych spin doktorów. Inni badacze (m.in. R. MacMullen, Some pictures in Ammianus Marcellinus' last books, „Art Bulletin” 46 (1964) 435-455) stoją na stanowisku, że utwory te były tylko elementem dworskiego ceremoniału. Dyskusję na ten temat podsumowuje krótko Alan Cameron (Claudian. Poetry and Propaganda at the Court of Honorius, Oxford 1970, 36-37). Por. MacCormack, Art and Ceremony, s. 145-146. Specyficznymi panegirykami były gratiarum actiones, gdzie wygłaszający prezentował obszernie samego siebie. Ciekawe rozważania na ten temat: J. Rogowski, Nauczyciel cesarza. Auzoniusz w „Gratiarum actio”, „Symbolae Philologorum Posnaniensium Graecae et Latinae" 19 (2009) 249-279.

${ }^{6}$ Szczegółowe informacje na temat początków i rozwoju panegiryków: D. Russell, The Panegiryst and their Teachers, w: The Propaganda of Power. The Role of Panegyric in Late Antiquity, ed. M. Whitby, Mnemosyne. Supplementum 183, Leiden - Boston - Köln 1998, 17-49.

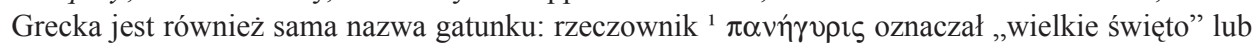
„uroczyste zgromadzenie”; por. Abramowiczówna III 381, s.v. $\pi \alpha v \eta ́ \gamma v \rho ı s$.

${ }^{7}$ Z twórczości Cycerona szczególne znaczenie mają mowy: De imperio Cn. Pompei (Pro lege Manilia), Pro Marcello, De Ligario oraz Pro rege Deiotaro. Kopalnię motywów i środków stylistycznych dla późniejszych panegirystów stanowiło również dzieło De clementia Seneki. W powszechnym użyciu pojęcie panegyricus zastąpiło laudatio dopiero w IV wieku.

${ }^{8}$ Szczegółowe rozważania dotyczące utworu Pliniusza, omawiające go na różnorodnych płaszczyznach: Pliny's praise: the Panegyricus in the Roman World, ed. P. Roche, Cambridge 2011.

${ }^{9}$ Więcej informacji na temat tego interesującego zbioru: In Praise of Later Roman Emperors. The Panegyrici Latini, Introduction, Translation and Historical Commentary with the Latin Text of R.A.B. Mynors, ed. C.E.V. Nixon and B.S. Rodgers, The Transformation of the Classical Heritage 21, Berkeley - Los Angeles - Oxford 1994, 3-37. 
pod wieloma względami, uznać za wzorcowe dla tego gatunku w późnym antyku. Stanowią one również punkt wyjścia do dalszego, niezwykle intensywnego rozwoju tego typu piśmiennictwa. Niemal historiograficzna narracja panegiryków okresu tetrarchii pod koniec wieku IV wyewoluowała w „eposy panegiryczne" Klaudiana, które w V w. stanowiły wzór dla Merobaudesa i Sydoniusza Apolinarego ${ }^{10}$. Te z kolei, pod wpływem ciagłego rozwoju ceremoniału dworskiego, a także zmian w sposobie postrzegania władcy, szczególnie na Wschodzie, przekształciły się w 2 poł. VI w. w utwory takie jak De laudibus Iustini Augusti libri IV Korippusa, gdzie będąca przedmiotem pochwały osoba władcy jest niezwykle mocno osadzona w rozbudowanym ceremoniale dworskim, w którym jej indywidualne cechy schodzą niejako na dalszy plan wobec potęgi Boga oraz siły idei władzy cesarskiej jako takiej.

Teoria twórczości panegirycznej kształtowała się wraz z rozwojem tego gatunku w sposób ciagły, a wielu autorów potrafiło zdobyć się na jej twórcze modyfikowanie. Tym niemniej pewne elementy składowe wydają się być niezwykle mocno zakorzenione. Również literatura pochwalna musiała podporządkować się ścisłym regułom sztuki retorycznej. Utwierdza nas w tym przekonaniu lektura traktatów teoretycznych, które szczegółowo omawiały prawidła rządzące sztuką komponowania panegiryków. Wśród nich na plan pierwszy zdecydowanie wysuwa się traktat Menandra Retora z Laodycei (III/IV w.), który badacze datują na koniec III wieku ${ }^{11}$. Jego największą zaletą jest przedstawienie odpowiedniego sposobu pochwały w zależności od okoliczności, na którą ma zostać sporządzona ${ }^{12}$. Na podstawie lektury Menandra, jak i innych traktatów oraz praktyki, można zauważyć, że wzorcowy panegiryk powinien mieć określoną budowę, a chwalenie odbywać się w odpowiedniej kolejności $^{13}$. Najpierw należało opisać miejsce pochodzenia oraz sławnych przodków. Następnie samo urodzenie oraz towarzyszące mu omina. Dalej przychodziła pora na fragment poświęcony młodości oraz wychowaniu. Jest on o tyle ważny, że pokazuje predyspozycje opiewanego do oczekiwanych zachowań, a także nierzadko uzasadnia powody późniejszych sukcesów. Kolejną rozbudowaną częścią winien być opis cnót i zachowań pożądanych w czasie wojny,

10 Pojęcie „Panegyrisches Epos” wprowadził do współczesnej terminologii H. Hofmann (Überlegungen zu einer Theorie der nichtchristlichen Epik der lateinischen Spätantike, „Philologus” 132 (1988) 134). Por. C. Schindler, Per Carmina Laudes. Untersuchungen zur spätantiken Verspanegyrik von Claudian bis Coripp, Beiträge zur Altertumskunde 253, Berlin - New York 2009, 2-5.

${ }^{11}$ Por. Russell, The Panegiryst and their Teachers, s. 28.

${ }^{12}$ Menander Retor wymienia takie okoliczności jak np. pieśń weselna, urodzinowa, pogrzebowa, pocieszająca, koronacyjna, lament, na powitanie, na pożegnanie, adres i inne.

${ }^{13} \mathrm{Na}$ teorię panegiryku późnoantycznego, poza pracą Menandra, wpływ miały również inne traktaty. Wśród nich na szczególną uwagę zasługuje znana praca Kwintyliana (ok. 35 - ok. 95) Institutiones, oraz dzieła takich autorów jak Eliusz Theon (2. poł. I w. po Chr.), Dion Chryzostom (ok. 40 - ok. 120), Eliusz Arystydes (117 - ok. 181), Pseudo-Dionizjusz z Halikarnasu (II w.), czy też Aftoniusz z Antiochii (2. poł. IV w.). 
a dopiero po nich przejście do dokonań czasu pokoju. Najistotniejsze, z naszego punktu widzenia, elementy znajdują się w części poświęconej dokonaniom chwalonej postaci podczas wojny, chociaż zobaczymy, że budowa wizerunku doskonałego wodza dostrzegalna jest na wielu płaszczyznach i w różnych częściach kompozycji. Nie wolno zapominać również, że poszczególni twórcy nierzadko zdobywali się na wprowadzenie pewnych zmian w przedstawionej powyżej kolejności, które miały dodać ich utworom oryginalnego rysu ${ }^{14}$.

\section{Ksztaltowanie wizerunku wodza jako element budowania lojalno-}

ści żołnierzy. Zastanawiając się dlaczego prezentacja władcy (lub członka jego najbliższego otoczenia) jako idealnego wodza miała dla panegirystów tak duże znaczenie, warto zwrócić uwagę jeszcze na jeden element. Literatura pochwalna już od samego początku miała silny oddźwięk, który można by określić jako „dydaktyczny”. Przedstawianie pewnych cech, jako budzących ogólny podziw, implikuje zachętę do odznaczania się nimi. Aspekt ten jest wyraźnie widoczny również w rzymskich panegirykach. Już w Panegiryku Pliniusza Młodszego wyraźnie można zaobserwować, że pochwała władcy jest równocześnie katalogiem cnót, którymi dobry princeps winien się odznaczać $^{15}$. Jakkolwiek realia znacznie się zmieniły, element ten daje się również odczuć w panegirykach późnoantycznych, zwłaszcza z IV i V stulecia. Budowany przez panegirystę obraz panującego to z założenia ilustracja doskonałości. Również w kontekście militarnym jako elementu koherentnego wizerunku, można tę tendencję odczuć bardzo silnie. Sukces na płaszczyźnie wojskowej zawsze był jednym z najważniejszych komponentów władzy politycznej, a w okresie późnego cesarstwa było o niego szczególnie trudno ${ }^{16}$. Co więcej, od śmierci Teodozjusza I (11 I 347 - 17 I 395; cesarz od 19 I 379) poszczególni władcy niezwykle rzadko brali bezpośredni udział w zmaganiach wojennych. Powody tego stanu rzeczy były z pewnością złożone, jednak faktem jest, że kolejnym cesarzem, który czynnie uczestniczył w działaniach zbrojnych, był dopiero Herakliusz (ok. 575 - 11 II 641; cesarz od 610), którego panowanie otwiera VII stulecie ${ }^{17}$. Równocześnie, przynajmniej do pewnego czasu,

${ }^{14} \mathrm{~W}$ tej materii szczególnie twórcze były panegiryki Klaudiusza Klaudiana, którego poezja, niezwykle ceniona w starożytności, zdobyła uznanie również wśród współczesnych badaczy.

${ }^{15} \mathrm{Na}$ temat cnót, których egzemplifikacji dokonał Pliniusz w swoim dziele, por. P. Roche, Pliny's Thankgivings: an introduction to the Panegyricus, w: Pliny's praise, s. 5-10. Element sugestii, jak powinien zachowywać się panujący szczególnie mocno widać u Seneki (De clementia I 1, 1, w: tenże, De la clémence, texte établi et traduit par F. Préchac, Collection des Universités de France, Paris $1967^{3}, 2$ ), gdzie autor już w pierwszych zdaniach sygnalizuje swoje zamierzenie: „Scribere de clementia, Nero Caesar, institui, ut quodam modo speculi uice fungerer et te tibi ostenderem peruenturum ad uoluptatem maximam omnium".

${ }^{16} \mathrm{Na}$ temat niezmiennej ideologii zwycięstwa w późnym antyku, por. Lee, War in Late Antiquity, s. 37-50.

${ }^{17}$ A.D. Lee (War in Late Antiquity, s. 34-37) omawia przyczyny, które utrudniały lub uniemoż- 
oczekiwano od panującego bezpośredniego zaangażowania w kampanie wojskowe, a jego brak stanowił skazę na wizerunku ${ }^{18}$. Być może więc panegiryk miał za zadanie spełniać równolegle dwie funkcje: przedstawiał opiewaną postać jako znakomitego wodza przed jego poddanymi, równocześnie stanowiąc informację zwrotną na temat tego, czego ci ostatni oczekują wobec rządzących $^{19}$. Wydaje się, że tylko w takich kategoriach można rozpatrywać

liwiały osobiste prowadzenie działań wojennych przez władców. Najczęstszymi był ich wiek (za młody lub za stary), brak predyspozycji militarnych, celowa polityka potężnych magistri militum (np. Stylichon, Aecjusz, Rycymer, Aspar), którzy spychali panujących na dalszy plan, perspektywa problemów sukcesyjnych w razie śmierci na polu bitwy (Walens, Julian) i inne. Od V w. nałożyła się na to tradycja stałego przebywania na dworze. Cesarzom takim jak Marcjan (ok. 390 - 27 I 457; cesarz od 25 VIII 450), Leon I (ok. 400 - 18 I 474; cesarz od 7 II 457), czy też Zenon (ok. 425 - 9 IV 491; cesarz: 9 II 474 - 9 I 475 i od sierpnia 476 do śmierci) trudno zarzucić brak przygotowania militarnego, a pomimo to nie prowadzili osobiście swoich wojsk do boju.

${ }^{18}$ Widać to wyraźnie w źródłach, gdzie autorzy negatywnie oceniają brak osobistego zaangażowania militarnego władcy. Synezjusz z Cyreny (De regno ad Arcadium imperatorem 9, PG 66, 1073A - 1076C, tłum. A. Kempfi: Synesios z Kyreny, Mowa do cesarza Arkadiusza czyli Zwierciadto doskonałego króla, „Meander” 17 (1962) z. 9, 451-452) zachęca władcę do osobistego kontaktu z wojskiem, tłumacząc jak różnorodne korzyści przynosi takie zaangażowanie. Znakomicie postulat Synezjusza oddaje A. Kempfi w polskim tłumaczeniu utworu: „... król musi się tak znać na sprawach

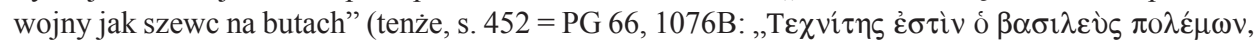

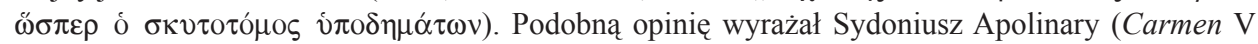
358nn, ed. W.B. Anderson, Sidonius Poems and Letters, vol 1, London - Cambridge (Mass.) 1936, 92, tłum. M. Brożek: Sydoniusz Apollinary, Listy i wiersze, Kraków 2004, 233) ubolewając nad ziemiami pozostawionymi przez władców bez obrony. Z kolei Ammian Marcelin (Res gestae XVI 12, 70, ed. J.C. Rolfe, Ammianus Marcellinus, [Res gestae], vol. 1: (Books XIV-XIX), LCL 300, London - Cambridge (Massachusetts) 1950², 300 i 302, thum. I. Lewandowski: Ammianus Marcellinus, Dzieje Rzymskie, t. 1, Warszawa 2002, 197) negatywnie oceniał władcę, który uzurpował sobie sukcesy innych i głosił, że walczył w pierwszym szeregu, podczas gdy nie było go nawet w pobliżu. Z czasem opisywana tendencja słabła i nie oczekiwano już od władców osobistego zaangażowania w działania zbrojne.

${ }^{19}$ Oczywiście kwestia jak silne faktycznie było to oddziaływanie winna być przedmiotem pogłębionej refleksji, a jej wynik trudno będzie kiedykolwiek uznać za ostateczny. Czy ktokolwiek wierzył w pochwały wyrażone w panegirykach trudno wyrokować z całą pewnością. Warto zacytować w tym kontekście zdanie św. Augustyna, które zawarł w swoich Wyznaniach (Confessiones VI 6, 9-11, ed. L. Verheijen, CCL 27, Turnholti 1981, 79: „quam ergo miser eram et quomodo egisti, ut sentirem miseriam meam die illo, quo, cum pararem recitare imperatori laudes, quibus plura mentirer, et mentienti faueretur ab scientibus [...]”, thum. Z. Kubiak: Św. Augustyn, Wyznania, Kraków 1998, 147: „Jakże byłem nieszczęśliwy! I jak postarałeś się o to, żebym odczuł moją niedolę w dniu, gdy przygotowywałem się do wygłoszenia mowy na cześć cesarza. Miałem w niej wiele nakłamać i zebrać rzęsiste oklaski od słuchaczy, którzy dobrze wiedzieli, jakie to są kłamstwa"). Być może ceremonie i wygłaszane przy ich okazji panegiryki porównać można współcześnie do obecności na liturgii eucharystycznej ludzi obojętnych (lub wręcz niechętnych) religijnie, których uwarunkowania społeczne zmuszają do takiego uczestnictwa. Wpływ słów oraz gestów, które się pojawią jest w ich przypadku prawdopodobnie znikomy. Jeżeli jednak moje porównanie jest trafne, to zawsze należy pamiętać o sporej grupie ludzi zaangażowanych w odbywającą się ceremonię. Proporcje jednych $\mathrm{i}$ drugich były jednak zawsze bardzo trudne do precyzyjnego oszacowania. Na koniec tej dygresji, 
przykładowo rozważania Klaudiana na temat talentów militarnych jedenastoletniego Honoriusza (9 XII 384 - 15 VIII 423; cesarz od 17 I 395), który takowych nigdy, również w przyszłości, nie przejawiał ${ }^{20}$.

Aspekt wojenny w panegirykach późnej starożytności miał wyjątkowe znaczenie również z innego powodu. Wobec rangi jaką sprawy militarne musiały zajmować w polityce Cesarstwa Rzymskiego, władca zmuszony był do dbania o armię, a sposób w jaki postrzegali go żołnierze miał znaczenie priorytetowe ${ }^{21}$. Okres późnego cesarstwa, który w powszechnym odbiorze kojarzy się raczej z wojnami zewnętrznymi (odpieranie najazdów barbarzyńców), nie był wolny również od konfliktów wewnętrznych. Być może ich częstotliwość i intensywność nie była tak wielka jak w III w., ale z pewnością lojalność własnych żołnierzy była dla rządzących bezcenna. Aby ją ugruntować, uciekano się do wielu różnych metod. Jedną z nich była z całą pewnością przysięga, którą żołnierze składali nie tylko na początku służby, ale również przy każdorazowym wstępowaniu nowego władcy na tron. Wojsko otrzymywało także szereg zachęt materialnych oraz specjalnych przywilejów (w trakcie i po zakończeniu służby), w tym ulgi podatkowe ${ }^{22}$. Nie bez znaczenia pozostawały również działania, które budowały więź indywidualną między cesarzem a jego żołnierzami: wygłaszanie mów, w których nazywał on żołnierzy swymi współtowarzyszami; nadawanie nazw oddziałom, które mocno powiązane były z danym władcą ${ }^{23}$; wydawanie serii monet, które poprzez swoją legendę podkreślały lojalność wojska. Jak więc można zaobserwować, władcy poświęcali niemało

wracając do okresu późnej starożytności, należy jeszcze podkreślić, że panegiryki skierowane były wyłącznie do odbiorców wyrobionych literacko i tylko tacy mogli je tak naprawdę zrozumieć. Była to grupa wąska, ale niezwykle wpływowa. Do szerokich mas skierowane były inne środki oddziaływania ideologicznego: epinikia (sprawozdania wojenne), tytulatura cesarska (np. zawierająca nazwy pokonanych ludów) oraz różnorodna sztuka plastyczna, szczególnie monety i ich legendy. Por. Lee, War in Late Antiquity, s. 38; B.H. Warmington, Aspects of Constantinian Propaganda in the Panegyrici Latini, „Transactions of the American Philological Association” 104 (1974) 372.

${ }^{20}$ Por. Lee, War in Late Antiquity, s. 32-33; W. Barr, Claudian's Panegyric of the Fourth Consulate of Honorius. Introduction, Text, Translation and Commentary, Liverpool 1981, 80; J. Lehner, Poesie und Politik in Claudians Panegyrikus auf das vierte Konsulat des Kaisers Honorius. Ein Kommentar, Beiträge zur Klassischen Philologie 163, Königstein im Taunus 1984, 65-67.

${ }^{21}$ Jak źle mogło skończyć się zaniedbanie na tym polu widać chociażby po losach cesarza Gracjana (18 IV 359 - 25 VIII 383; cesarz od 17 XI 375), którego armia opuściła całkowicie pod Lutecją (383).

${ }^{22}$ Więcej na ten temat por. A.H.M. Jones, The Later Roman Empire, Oxford 1964, 635; M.J. Nicasie, Twilight of Empire. The Roman Army from the Reign of Diocletian until the Battle of Adrianople, Amsterdam 1998, 92-94; Lee, War in Late Antiquity, s. 57-66 i passim.

${ }^{23}$ Miało to miejsce nawet (a może szczególnie) wówczas, gdy władca nie prowadził osobiście swoich ludzi do walki. Por. Lee, War in Late Antiquity, s. 65. Notita Dignitatum zawiera liczne oddziały nawiązujące do imienia Arkadiusza np. Felices Arcadiani seniores (Notitia dignitatum VII 36, ed. O. Seeck, Frankfurt am Main 1962, 21), czy też Honoriusza np. Felices Honoriani iuniores (tamże V 62, ed. Seeck, s. 14). 
energii, aby zapewnić sobie wierność swoich żołnierzy. Na jej zdobycie składał się oczywiście szereg różnorodnych czynników, jednak nic nie było tak skuteczne jak powodzenie w walce. Zwycięstwa najlepiej cementowały więź pomiędzy wodzem a jego wojskiem, jednak w sytuacji, w której znalazło się cesarstwo między IV a VI w., było o nie niezwykle trudno. Wobec tego po raz kolejny możemy zaobserwować, jak ważna rola przypadała w udziale panegiryście. Stworzenie i ugruntowanie wizerunku rządzącego jako idealnego wodza było niezwykle pożądane również ze względu na armię. Nie wolno także zapominać, że rola wojska w samym ceremoniale była również niebagatelna - opisują ją cesarskie panegiryki, ale również inne źródła ${ }^{24}$. Trudno wyobrazić sobie cesarską intronizację bez publicznie wyrażonej akceptacji ze strony żołnierzy. Nie mogło więc, podczas misternie przygotowanej uroczystości, zabraknąć miejsca na pochwałę rządzącego jako znakomitego wodza. Wszystkie te czynniki przenikały się ze sobą, tworząc złożony obraz elementów życia społecznego późnego Cesarstwa Rzymskiego.

Okazji do wygłaszania panegiryków w interesującym nas okresie było mnóstwo, a zachowane do naszego czasu utwory stanowią tylko niewielką część tych, które musiały zostać skomponowane ${ }^{25}$. Każda uroczystość z udziałem cesarza (adventus, triumf, nadanie konsulatu, rocznica wstąpienia na tron) miała w swoim programie miejsce na wygłoszenie pochwały. Twórcy utworów panegirycznych cieszyli się wobec tego dużym wzięciem. Kariery Klaudiana, Merobaudesa, czy też innych panegirystów są tego znakomitym przykładem. Zrozumiałe jest, że przy tak dużej ilości komponowanych dzieł ich narracja była w znacznym stopniu konwencjonalna. Prawdziwym szacunkiem cieszyli się więc autorzy, którzy, mieszcząc się w kanonach sztuki retorycznej, potrafili dodać do swoich utworów element oryginalności. Jeżeli potrafili przy tym wywołać zainteresowanie i podziw zgromadzonej publiczność, to ich sława rozbrzmiewała echem po całym imperium, otwierając im drogę do najwyższych zaszczytów w państwie. Nie dziwi zatem fakt, że panegiryki układano chętnie, a wielu twórców wprowadziło powiew świeżości w utarte schematy ${ }^{26}$. Warto zatem prześledzić jak kształtował się rozwój

${ }^{24}$ Szczególnie ciekawy i wiarygodny jest fragment dzieła Konstantyna Porfirogenety (905 9 XI 959; cesarz od 9 VI 913) (Constantini Pophyrogeniti imperatoris de ceremoniis byzantini, libri duo I 91, ed. J.J. Reiske, CSHB 5, Bonn 1829, 410-412) z opisem intronizacji Leona I.

${ }^{25}$ Por. S. MacCormack, Latin Prose Panegyrics, w: Empire and Aftermath, Silver Latin 2, ed. T.A. Dorey, London - Boston 1975, 151.

${ }^{26}$ Głównym przedmiotem zainteresowania niniejszego artykułu jest sposób w jaki przedstawiano wodza w panegirykach oraz zmiany w nim zachodzące. Zmuszony zatem jestem pominąć rozważania na inne, nie związane z tym bezpośrednio, kwestie. Na temat rozwoju samego gatunku, por. T. Nissen, Historisches Epos und Panegyrikos in der Spätantike, „Hermes” 75 (1940) 298-325; T. Hägg - P. Rousseau, Greek Biography and Panegyric in Late Antiquity, Berkeley - Los Angeles - Oxford 2000; MacCormack, Latin Prose Panegyrics, s. 143-205. 
wizerunku wodza w komponowanych utworach i przy pomocy jakich środków poeci przekonywali publiczność o wysokich kompetencjach militarnych poszczególnych wodzów.

3. Obraz wodza w panegirykach. Pierwszym aspektem, na który chciałbym zwrócić uwagę, jest zasób epitetów i określeń stosowanych wobec chwalonej postaci, które powiązać można $\mathrm{z}$ tematyką militarną. W panegirykach okresu wcześniejszego, szczególnie czasów tetrarchii, władca określany jest jako caesar, augustus, princeps lub imperator. Choć tylko ostatnie z tych określeń samo przez się implikuje powiązanie ze sferą wojskowa, to jednak trzeba przyznać, że niemal żadne z wymienionych nie pojawia się samodzielnie, bez dodatkowego epitetu. Aby zbudować wizerunek władcy - doskonałego wodza, określano go takimi przymiotnikami jak invictus (również w stopniu najwyższym jako invictissimus) lub fortissimus. Zwłaszcza w panegirykach okresu tetrarchii zawartych w zbiorze XII Panegyrici Latini pojawiają się one szczególnie często ${ }^{27}$. Żaden inny z epitetów władcy nie może się z nimi równać pod względem częstotliwości ${ }^{28}$. Kolejne określenia takie jak sacratissime i piissime pojawiają się nieporównywalnie rzadziej, a optimus, czy też maximus zupełnie sporadycznie. Widać wyraźnie, że ideologia dzielności osobistej oraz powiązanego z nią zwycięstwa militarnego była niezmiernie istotna dla cesarzy okresu tetrarchii i starano się wyraźnie ją podkreślić, wykorzystując adekwatne epitety. Jest to o tyle warte uwagi, że w późniejszym okresie ta forma wyrazu schodzi zdecydowanie na dalszy plan. Już na przełomie IV i V w., kiedy powstawały najpóźniejsze chronologicznie panegiryki ze zbioru XII $\mathrm{Pa}$ negyrici Latini oraz utwory Klaudiana, częstotliwość występowania formy invictus imperator (lub jej pokrewnych) jest znacznie mniejsza ${ }^{29}$. Przykładowo

${ }^{27} \mathrm{~W}$ dyskusji naukowej na ten temat pojawiają się hipotezy jakoby miałoby to być powiązane z kultem Sol Invictus oraz cesarza jako Apollina, ale zdania na ten temat są podzielone, por. In Praise of Later Roman Emperor, s. 230, nota 36.

${ }^{28}$ Przykładowo w panegiryku na cześć cesarza Konstancjusza wygłoszonym po restytucji Brytanii określenie Caesar invictus pojawia się jedenaście razy (Panegyricus Constantio Caesari dictus 1, 1, ed. R.A.B. Mynors, w: In Praise of Later Roman Emperors, s. 543; 2, 2, ed. Mynors, s. 544; 5, 4, ed. Mynors, s. 545; 9, 6, ed. Mynors, s. 547; 13, 4, ed. Mynors, s. 549; 14, 3, ed. Mynors, s. 549; 15, 5, ed. Mynors, s. 550; 17, 1, ed. Mynors, s. 551; 17, 3, ed. Mynors, s. 551; 21, 1, ed. Mynors, s. 553; 21, 3, ed. Mynors, s. 553), a do tego jeszcze dwukrotnie wobec współrządzących invictissimi principes (tamże 3, 2, ed. Mynors, s. 544; 20, 5, ed. Mynors, s. 553). W innych panegirykach kwestie te wyglądają rozmaicie.

${ }^{29}$ Nieco inaczej potraktował te kwestie Auzoniusz (ok. 310 - ok. 395), który ani razu nie nawiązał bezpośrednio do niezwyciężoności panującego. Jest to o tyle ciekawe, że w swoim utworze korzystał on z epitetów wielokrotnie i różnorodnie. Tylko raz użył określania imperator fortissimus (Gratiarum actio III, ed. w: Ausonius with an English translation by H.G. Evelyn-White, vol. 2, LCL 115, London - New York 1921, 222). Pojawiają się również u niego takie element tytulatury jak Germanicus, Alamannicus i Sarmaticus (tamże II, LCL 115, 224) jako epitety władcy, co jest zjawiskiem rzadkim, a wyraźnie nawiązującym do sukcesów militarnych. Najwięcej razy odnaleźć 
w panegiryku Mamertyna (2. poł. IV w.) poświęconym cesarzowi Julianowi (ok. 331 - 26 VI 363; cesarz od 3 XI 361), wśród licznych epitetów, którymi twórca obdarza władcę, nie znajdujemy ani razu odwołania bezpośredniego do jego dzielności i męstwa ${ }^{30}$. Tak samo jest w panegiryku Pakatusa (2. poł. IV w.) na cześć cesarza Teodozjusza ${ }^{31}$. Ta tendencja wyraźnie utrzymuje się dalej i przykładowo w panegiryku na cześć cesarza Anastazjusza (ok. 430 - 9 VII 518; cesarz od 11 IV 491), wśród różnorodnych określeń władcy, epitet invictus princeps pojawia się tylko $\mathrm{raz}^{32}$. Nie oznacza to oczywiście, że rola panującego jako głównodowodzącego była zupełnie pomijana. Każdy z panegiryków późnoantycznych dotykał sfery wojskowej. Już na tym prostym przykładzie widać wyraźnie, że akcenty pochwały ulegały z czasem przesunięciu ${ }^{33}$.

Epitety utrwalające wizerunek znakomitego, zwycięskiego wodza to najbardziej oczywiste, a przy tym niezbyt wyrafinowane narzędzie w zasobach panegirystów. Od twórców wyspecjalizowanych i cenionych za swą sztukę wymagano daleko bardziej urozmaiconych sposobów pochwały. Jednym ze środków do jej wyrażenia był opis miejsca urodzenia chwalonego. Ten pozornie zupełnie nie związany z tematem element $w$ ręku dobrego panegirysty mógł być znakomicie wykorzystany. Dobrze zapowiadający się dowódca winien wywodzić się z terenów posiadających militarne tradycje. W rzeczywistości

możemy określenie piissimus (tamże IV, LCL 115, 228; V, LCL 115, 232; IX, LCL 115, 244; X, LCL 115, 244; XVIII, LCL 115, 266), co pokazuje kierunek, w jakim podążał rozwój panegiryków.

${ }^{30}$ Określenie imperator bez doprecyzowania pojawia się ponad dwadzieścia razy. Kilkakrotnie określany jest on jako maximus (Gratiarum actio [Claudii] Mamertini de consulatu suo Iuliano Imperatori 2, 5, ed. R.A.B. Mynors, w: In Praise of Later Roman Emperors, s. 630; 9, 4, ed. Mynors, s. 633; 14, 6, ed. Mynors, s. 636; 17, 1, ed. Mynors, s. 637; 21, 4, ed. Mynors, s. 640; 23, 4, ed. Mynors, s. 641; 28, 2, ed. Mynors, s. 643) oraz sanctissimus (tamże 12, 2, ed. Mynors, s. 635; 18, 3, ed. Mynors, s. 638; 31, 1, ed. Mynors, s. 645; 32, 3, ed. Mynors, s. 645). Oprócz tego odnaleźć możemy jeszcze kilka innych epitetów, ale żaden z nich nie jest bezpośrednio związany ze sferą wojskową. Co więcej, sam termin imperator w kontekście tego utworu wydaje się być pozbawionym jakichkolwiek konotacji militarnych.

${ }^{31}$ Zawołanie imperator pojawia się wielokrotnie (Panegyricus latini Pacati Drepani dictus Theodosio 6, 1, ed. R.A.B. Mynors, w: In Praise of Later Roman Emperors, s. 650; 6, 4, ed. Mynors, s. 650; 8, 1, ed. Mynors, s. 651; 10, 1, ed. Mynors, s. 652; 18, 3, ed. Mynors, s. 657; 22, 2, ed, Mynors, s. 659; 23, 1, ed. Mynors, s. 660; 24, 3, ed. Mynors, s. 660; 30, 2, ed. Mynors, s. 663; 32, 1, ed. Mynors, s. 664; 33, 5, ed. Mynors, s. 666; 40, 1, ed. Mynors, s. 669; 40, 2, ed. Mynors, s. 669; 44, 3, ed. Mynors, s. 672; 45, 4, ed. Mynors, s. 672; 45, 7, ed. Mynors, s. 673; 47, 6, ed. Mynors, s. 674), ale pozbawione jest interesujących nas, precyzujących określeń.

${ }^{32}$ Por. Priscianus, De laude Anastasii Imperatoris 63, ed. P. Coyne, Priscian of Caesarea's „, De Laude Anastasii Imperatoris", Translation and Commentary, Hamilton 1988, 50. W całym utworze widać wyraźnie, że akcenty były już wówczas inaczej rozłożone, a autor najczęściej nawiązuje do sprawiedliwości władcy i jego prerogatyw sądowych.

${ }^{33} \mathrm{~W}$ efekcie tej ewolucji powstał zupełnie nowy gatunek, który można określić jako panegiryk chrześcijański. Cesarz zaczyna być wychwalany nie za swoje umiejętności wojskowe, lecz za wiarę i pokorę, por. In Praise of Later Roman Emperor, s. 439-440; MacCormack, Latin Prose Panegyrics, s. 169-172. 
istniały na terenie cesarstwa takie regiony, jak np. Bałkany, z których rekruci byli bardziej pożądani niż z innych. Fakt ten jednak z punktu widzenia panegirysty był tak naprawdę mało znaczący. Dla każdej krainy imperium można było znaleźć jakąśs wybitną postać, jakieś chwalebne wydarzenie lub jakieś logiczne uzasadnienie legitymizujące ją jako miejsce odpowiednie dla narodzin znakomitego wodza. Aby zilustrować tę tezę można przytoczyć różnorodne przykłady. W panegiryku na cześć cesarza Teodozjusza, którego autorem był Latinus (Latinius) Pacatus Drepanius, rodzinna Hiszpania to miejsce, które wydaje najtwardszych żołnierzy oraz najbieglejszych w sztuce wojennej wodzów ${ }^{34}$. Sydoniusz Apolinary w swoim panegiryku na cześć cesarza Awitusa (ok. 392 - 457; cesarz od 9 VII 455 - 17 X 456) wspomina, że urodził się on w krainie Arwernów, gdzie pod Gergowią (52 prz. Chr.) sam Juliusz Cezar (12 VII 100 - 15 III 44 prz. Chr.) został pokonany ${ }^{35}$.

Oprócz tego, że wychwalana osoba urodziła się w miejscu predestynującym do stania się znakomitym dowódca, posiadała ona również przodków, od których odziedziczyła zdolności wojskowe. Antenaci byli biegli w sztuce wojennej, a ich zasługi na tym polu wielokrotnie pomnażały chwałę Rzymu. Czytając więc panegiryk napisany z okazji czwartego konsulatu cesarza Honoriusza otrzymujemy niezwykle rozbudowany opis zasług wojennych jego ojca, Teodozjusza, który panując „od Gades do Tygrysu oraz od Tanais do Nilu" zwyciężył wszystkie krainy, nieustannie triumfując ${ }^{36}$. Klaudian wspomniał o walkach na Bałkanach, nad Dunajem, w Tracji i Mezji, a szczegółowo zajął się opisem sposobu, w jaki Teodozjusz stłumił rewoltę Magnusa Maksymusa (ok. 335 - 28 VIII 388) oraz Eugeniusza (ok. 345 - 6 IX 394) i Arbogasta († 8 IX 394). Cały ten opis czynów wojennych zajął 70 wersów. W ślady Klaudiana poszli jego bezpośredni następcy: Merobaudes i Sydoniusz Apolinary. Pierwszy z nich, w panegiryku napisanym najprawdopodobniej na cześć magistrum militum Aecjusza (ok. 390 - 21 IX 454), z okazji trzeciego konsulatu wodza, wychwala ojca Aecjusza, Gaudencjusza $(† 425)^{37}$. Z kolei Sydoniusz Apolinary wspomina o Prokopiuszu (ok. 365 - ok. 430), ojcu cesarza Antemiusza (ok. 420 - 11 VII 472; cesarz od 12 IV 467), który stanął na czele armii, zamknął przełęcze Taurusu i zwyciężywszy przeciwnika

${ }^{34}$ Określana jest również jako mater principum (Panegyricus latini Pacati Drepani dictus Theodosio 4, 5, ed. Mynors, s. 649).

${ }^{35}$ Por. Sidonius Apollinaris, Carmen VII 148-152, ed. Anderson, s. 130. Jak widać, nawiązanie militarne nie musiało być korzystne dla rzymskiego oręża. Warto jeszcze dodać, że nierzadko poszczególne krainy niemal spierają się, która z nich wydała chwaloną postać, por. Claudianus, Panegyricus de quarto consulatu Honorii Augustii 127-130, ed. M. Platnauer, vol. 1, London Cambridge (Mass.) 1990, 296.

${ }^{36}$ Jest on tak obszerny, że można odnieść wrażenie, iż to właśnie Teodozjusz (który już wówczas nie żył) jest właściwym adresatem tego panegiryku.

37 Rozważania na temat autorstwa i okazji wygłoszenia panegiryku: A. Szopa, Flavius Merobaudes. Wódz i poeta z V wieku, Kraków 2014, 146-147. 
doszedł wraz z żołnierzami do samego Orontesu ${ }^{38}$. Tego typu nawiązania pojawiają się w twórczości panegirycznej wielokrotnie. Nierzadko jednak mamy do czynienia z odwołaniami do dalszych przodków, dziadków chwalonych osób. W panegiryku Klaudiana z okazji trzeciego konsulatu Honoriusza odnaleźć możemy wspomnienie czynów Flawiusza Teodozjusza (†376), dziadka Honoriusza, którego dokonania militarne predestynują go do porównywania z Achillesem ${ }^{39}$. Sławnych przodków przywoływano również, żeby podkreślić na ich tle dokonania chwalonego. W panegiryku dwunastym zbioru XII Panegyrici Latini, poświęconym wychwalaniu cesarza Konstantyna I (ok. 272 - 22 V 337; cesarz od 25 VII 306) pojawia się wzmianka, że przewyższył on wszystkich antycznych wodzów, a wśród nich nawet swojego ojca, Konstancjusza Chlorusa (ok. 250 - 25 VII 306; tetrarcha od 1 III 293) ${ }^{40}$. O tym, że pochodzenie ze słynnego rodu miało dla starożytnych niebagatelne znacznie przekonuje nas Pakatus w panegiryku na część cesarza Teodozjusza, gdzie zestawiając władcę z uzurpatorem Maksymusem wspomina, że ojciec pierwszego był triumfującym wodzem, a pochodzenie drugiego jest nieznane ${ }^{41}$. Co ciekawe, nawet z pochodzenia, które wydawać by się mogło niezbyt chwalebne, dobry panegirysta jest w stanie uczynić atut. We wspomnianym panegiryku dla cesarza Antemiusza pojawia się postać Rycymera (ok. 405 - 18 VIII $472)^{42}$. Ponownie mamy tu antytetyczne zestawienie patrycjusza rzymskiego z królem Wandalów, Gejzerykiem (ok. 390 - 25 I 477; król od 428) ${ }^{43}$. Podczas gdy ten drugi ma niepewnego ojca, a matką jego była niewolnica, to Rycymer wywodzi swój ród równocześnie z dwóch plemion barbarzyńskich: Swebów i Wizygotów, co nagle staje się powodem do wyjątkowej dumy ${ }^{44}$. Na podstawie tego fragmentu możemy zaobserwować nie tylko, że w dalszym ciągu pochodzenie miało duże znaczenie dla odpowiedniej prezentacji wychwalanego, ale również to, że coś co nie uchodziło za zaletę w powszechnym odbiorze, pod piórem panegirysty mogło się nią stać.

${ }^{38}$ Por. Sidonius Apollinaris, Carmen II 89-93, ed. Anderson, s. 14. Por. J. Styka, Sydoniusz Apollinaris i kultura literacka $w$ Galii $w$ V wieku, Kraków 2008, 118. Na temat Prokopiusza, ojca Antemiusza, por. The Prosopography of Later Roman Empire, vol. 2: A.D. 395-527, ed. by J.R. Martindale, Cambridge 1980, 920.

${ }^{39}$ Por. Claudianus, Panegyricus de tertio consulatu Honorii Augusti 51-62, ed. M. Platnauer, vol. 1, London - Cambridge (Mass.) 1990, 274.

${ }^{40}$ Por. Panegyricus dictus Constantino Filio Constantii 24, 3-4, ed. R.A.B. Mynors, w: In Praise of Later Roman Emperors, s. 606-607.

${ }^{41}$ Fragment ten stanowi nie tylko pochwałę Teodozjusza I, ale ma też na celu zdeprecjonowanie jego oponenta, por. Panegyricus latini Pacati Drepani dictus Theodosio 31, 1, ed. Mynors, s. 664.

${ }^{42}$ Por. Sidonius Apollinaris, Carmen II 358-362, ed. Anderson, s. 38.

${ }^{43}$ Gejzeryk nie został tu wspomniany z imienia, co jest cechą charakterystyczną gatunku, por. MacCormack, Latin prose panegyrics, s. 160.

${ }^{44} \mathrm{Na}$ temat pochodzenia Rycymera, por. M. Wilczyński, Germanie w stużbie zachodniorzymskiej w V w. n.e. Studium historyczno-prosopograficzne, Kraków 2001, 289-290. 
Po opisie przodków sławnych ze swych orężnych czynów należało właściwie zaprezentować dzieciństwo chwalonego. Ten fragment panegiryków mógłby być dla współczesnych badaczy niezwykle cenny, ponieważ inne źródła rzadko podają informacje na temat wczesnego okresu życia wielu z omawianych postaci. Niestety, informacje zawarte w poświęconych dzieciństwu i wczesnej młodości passusach mają najczęściej topiczny charakter. Chwalona postać, odkąd tylko nauczy się chodzić, odznacza się niezwykłą siłą i hartem ducha, i każdy może dostrzec w niej cechy właściwe dla dobrego wojownika. Pełen katalog ćwiczeń dla przyszłego wodza wymienia Klaudian w panegiryku z okazji trzeciego konsulatu Honoriusza. Młody władca już od lat dziecięcych przyzwyczajony był do obozu wojskowego. Jego zabawkami były łupy pobitych wrogów ${ }^{45}$. Gdy tylko zaczął pewnie stawiać kroki, ojciec zadbał o to, aby nie miał żadnej okazji do bezczynności. Każdy dzień wiązał się z surowym treningiem, a wśród kanonicznego zestawu ćwiczeń znajdywały się: wystawianie na zimno, na niepogodę, na gorąco, przepływanie rwących potoków, wspinanie na niezdobyte szczyty, przeskakiwanie wąwozów i dolin, przebieganie równin, przetrzymywanie bezsennych nocy na warcie oraz hartowanie $\mathrm{w}$ innych tego typu warunkach ${ }^{46}$. Tak surowe prowadzenie młodego władcy miało oczywiście służyć wyrobieniu jego charakteru i przyzwyczaić go do przyszłych trudów ewentualnych wojen ${ }^{47}$. Warty przytoczenia jest również obraz, jaki buduje Flawiusz Merobaudes w swoim II Panegiryku ${ }^{48}$. Oto opiewany Aecjusz, gdy tylko zaczął chodzić, hartował swe ciało przebywaniem

${ }^{45}$ Por. Claudianus, Panegyricus de tertio consulatu Honorii Augusti 22-38, ed. Platnauer, vol. 1, s. 272, gdzie autor buduje uroczą scenę przedstawiając w niej małego Honoriusza, który uściskiem wita zbroczonego krwią ojca, Teodozjusza, gdy ten wraca po zwycięskiej walce z barbarzyńcami z Północy.

${ }^{46}$ Por. tamże 39-55, ed. Platnauer, vol. 1, s. 272-274.

${ }^{47}$ Budowany przez Klaudiana obraz jest niestety zupełnie nieprawdziwy. Honoriusz nie przejawiał żadnych talentów wojskowych, a całe swoje panowanie spędził w poszczególnych rezydencjach cesarskich. Nie wiemy na pewno, jakie było jego usposobienie, ale już starożytni nie wystawiali mu najlepszego świadectwa. Prokopiusz z Cezarei przytacza anegdotę (De bellis III 2, 25-26, ed. H.B. Dewing: Procopius, History of the Wars, Book III-IV, London - Cambridge (Mass.) 2006, 17, thum. D. Brodka: Prokopiusz z Cezarei, Księga wojen, t. 1, Kraków 2014, 206), jakoby cesarz na wieść o upadku Rzymu miał wpaść w przerażanie, gdyż słysząc Roma capta przestraszył się, że chodziło o jego ulubionego koguta o imieniu Roma. Gdy dowiedział się, że chodzi o miasto, znacznie się uspokoił. Sam Klaudian zdaje się potwierdzać właśnie taki wizerunek wodza, ponieważ w panegiryku na czwarty konsulat Honoriusza (Panegyricus de quarto consulatu Honorii Augustii 122-127, ed. Platnauer, vol. 1, s. 294-296) prezentuje obraz władcy wychowanego jedynie w purpurze, aby nic nie mogło zbrukać jego świętej osoby. Oczywiście, jako dobry panegirysta Klaudian czyni z tego wielki atut panującego.

${ }^{48}$ Merobaudes, Panegyricus II 121-143, w: tenże, Carminum fragmenta. Panegyricorum in consulatu Aetii fragmenta, ed. F. Vollmer, MGH Auctores Antiquissimi XIV, Berolini 1905, 16, tłum. A. Szopa, w: Flavius Merobaudes, s. 225. 
w zimnym klimacie i od lat dziecięcych ćwiczył się w rzemiośle wojennym ${ }^{49}$. Merobaudes wykorzystał dalej fakt, iż młodzieniec był zakładnikiem u Gotów Alaryka (ok. 395-410; król od 395) oraz u Hunów Rugili († 434) ${ }^{50}$. Roztoczył przed audytorium obraz chłopca, którego zdolności w posługiwaniu się bronią wzbudzały podziw nawet u dzikich barbarzyńców. Ich zachwyt był tak duży, że pozwalali mu na doskonalenie umiejętności, które przecież potem miały być wykorzystane przeciwko nim. Należy również wspomnieć, że w opisie dzieciństwa nie mogło zabraknąć też edukacji wojskowej. Samo zahartowanie mogło wystarczyć żołnierzowi, ale z pewnością było to za mało dla wodza. Idealny model edukacyjny zawierał dwa elementy: praktyczny i teoretyczny. Pierwszy z nich znakomicie przedstawił anonimowy autor, nazywany w niektórych manuskryptach Mamertinusem, w swoim panegiryku na cześć Mak-

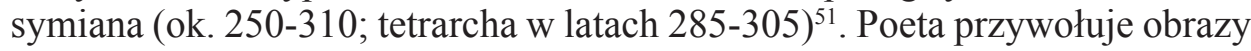
z dzieciństwa tetrarchy:

„kształciłeś się i wzrastałeś na owym limesie, w siedzibie najdzielniejszych legionów, wśród bieganiny dziarskich młodzieńców, gdzie szczęk oręża zagłuszał twe dziecięce kwilenia"s2.

Drugi z kolei przybliżył nam Sydoniusz Apolinary w panegiryku na cześć Antemiusza:

„Dojrzewający umysł kształcił się muzami i Cyceronem, / którym rozbrzmiewa twój głos; uczył się też dziejów / Tych dawnych wodzów, poznawał bitwy i z ksiąg wyczytywał, co robić na polu boju" ${ }^{53}$.

Jak widać dostrzegano przydatność obu rodzajów edukacji, a panegiryści czynili z nich wielki powód do pochwały.

Opis miejsca urodzenia, przodków oraz młodości mógł stanowić jedynie wstęp do najważniejszej części składowej budowanego obrazu. Doskonały wódz powinien przede wszystkim pokazywać się w boju i tam winny się objawiać wszelkie jego przymioty. Pierwszym z nich jest siła autorytetu, która wywołuje ponadnaturalny strach wśród wrogów. Element ten znajdujemy

49 Wystawienie niemowląt na śnieg było niezwykle popularnym toposem, por. Sidonius Apollinaris, Carmen VII 171-173, ed. Anderson, s. 132.

${ }^{50} \mathrm{Na}$ temat pobytu u Hunów, por. T. Stickler, Aëtius. Gestaltungsspielräume eines Heermeisters im ausgehenden Weströmischen Reiches, Vestigia 54, München 2002, 23.

${ }^{51} \mathrm{Na}$ temat problemów z ustaleniem autorstwa znajdującego się w zbiorze XII Panegyrici Latini panegiryku na cześć Maksymiana, por. In Praise of Later Roman Emperor, s. 41-42.

${ }^{52}$ Por. Mamertini (?) Panegyricus Maximiano Augusto dictus 2, 4, ed. R.A.B. Mynors, w: In Praise of Later Roman Emperors, s. 524: „An quamadmodum educatus institutusque sis praedicabo in illo limite, illa fortissimarum sede legionum, inter discursus strenuae iuventutis et armorum sonitus tuis vagitibus obstrepantes?", thum. własne.

${ }^{53}$ Sidonius Apollinaris, Carmen VII 174-177, ed. Anderson, s. 132: ,surgentes animi Musis formantur et illo quo Cicerone tonas; didicit quoque facta tuorum ante ducum; didicit pugnas libroque relegit quae gereret campo", thum. Brożek, s. 204. 
W wielu panegirykach. Barbarzyńcy zostają wręcz porażeni samym majestatem władcy, co często pozwala zakończyć działania wojenne przed ich faktycznym rozpoczęciem. Już same narodziny Honoriusza sprawiły, że

„dzika Germania drży wzdłuż całego Renu, a Kaukaz ze strachu porusza swymi lasami" ${ }^{54}$.

Konstancjusz (Chlorus) zanim wyruszył na wyprawę do Brytanii zabezpieczył granicę na Renie wywołując strach wśród barbarzyńców, ale nie przy pomocy legionów, tylko samą obecnością ${ }^{55}$. Nieco bardziej prawdopodobny powód tego nadnaturalnego strachu wśród barbarzyńców przekazuje nam Nazariusz (IV w.) w panegiryku na cześć Konstantyna. Wspomina on też o Kryspusie (ok. 305-326), synu Konstantyna, który miażdżąc przeciwnika zaczął budować wokół siebie aurę strachu, podobnie jak wcześniej jego ojciec ${ }^{56}$. Z pewnością brutalne pacyfikacje były najskuteczniejszym środkiem do wzbudzania nabożnego lęku wśród barbarzyńców. Czasami porażenie przeciwnika strachem mogło mieć swoje złe strony. Przekonał się o tym Konstantyn I, ponieważ do tego stopnia sparaliżował wrogów, że żaden nie śmiał rzucić mu wyzwania i z tego powodu władca nie mógł dokonać godnych upamiętnienia czynów wojennych w takiej ilości, jakiej by sobie życzy ${ }^{57}$.

Niezależnie od przerażenia wrogów, niejednokrotnie wódz zmuszony był jednak prowadzić swoich żołnierzy do boju. Wówczas musiał on okazać się znakomitym taktykiem. Przedstawienie szczegółów walk interesowało raczej tylko twórców panegiryków z okresu przełomu III i IV wieku. Jedynie wówczas znajdujemy opisy kampanii, w których panegiryści zwracali uwagę na wiarygodność, tworząc obraz nieznacznie tylko różniący się od historiograficznego. Znakomitym przykładem mogą być dwa utwory ze zbioru XII Panegyrici Latini, a mianowicie Panegiryk XII oraz Panegiryk IV, oba skomponowane na cześć cesarza Konstantyna. W jednym i drugim utworze opisana została kampania z 312 r., podczas której władca uderzył na Italię, aby pokonać Maksencjusza (ok. 280 - 28 X 312; cesarzy od 28 X 306). Co ciekawe, jest w nich znacznie mniej cech charakterystycznych dla innych panegiryków, takich jak wspomniane już kwestie ojczyzny, przodków, czy też młodości.

${ }^{54}$ Por. Claudianus Panegyricus de tertio consulatu Honorii Augusti 18-20, ed. Platnauer, vol. 1, s. 271-272.

${ }_{55}^{5}$ Por. Panegyricus Constantio Caesari dictus 13, 3, ed. Mynors, s. 549.

${ }^{56}$ Por. Panegyricus Nazarii dictus Constantino 3, 5, ed. R.A.B. Mynors, w: In Praise of Later Roman Emperors, s. 610. Zob. Panegyricus dictus Constantino Filio Constantii 22, 3, ed. Mynors, s. 605; Panegyricus Constantino Augusto dictus 12, 2nn, ed. R.A.B. Mynors, w: In Praise of Later Roman Emperors, s. 578nn, gdzie mowa o okrutnych działaniach Konstantyna.

${ }^{57}$ Por. Gratiarum actio Constantino Augusto 4, 4, ed. R.A.B. Mynors, w: In Praise of Later Roman Emperors, s. 587. Motyw porażenia przeciwnika strachem przez Konstantyna pojawia się jeszcze w Panegyricus Constantino Augusto dictus 10, 4, ed. Mynors, s. 577, a także w Panegyricus dictus Constantino Filio Constantii 2, 6, ed. Mynors, s. 595. 
Autorzy skoncentrowali się bardziej na niemal historiograficznym opisie kampanii, tworząc jej oficjalnie przyjętą wersję. Na szczególną uwagę zasługują panoramy bitew pod Turynem oraz Werona, które miały fundamentalne znaczenie dla przebiegu całej kampanii ${ }^{58}$. Panegiryści, opisując szczegółowo działania zbrojne, nie unikają ekfraz oraz dygresji, a mimo to tworzą całościowy obraz, który pozwala docenić geniusz militarny Konstantyna, o co w końcu w panegiryku chodziło. Pewne jest, że mamy tutaj do czynienia z oficjalną wersją wydarzeń zwycięskiej strony. Jednak pozwala nam to zwrócić uwagę na kolejny sposób budowania obrazu wodza doskonałego. Staje się on jeszcze ciekawszy, jeżeli przyjrzymy się opisowi kampanii zbrojnych w późniejszych panegirykach. Przykładowo, gdy Merobaudes opisuje wielkie zwycięstwo Aecjusza pod Mons Colubrarius, nie otrzymujemy niemal żadnej konkretnej informacji o przebiegu samego starcia i taktyce wodza ${ }^{59}$. Oprócz informacji, że atak nastapił niespodziewanie, a w walce brały udział jazda i piechota nie dowiadujemy się niemal nic. Skoro Aecjusz starcie wygrał, to musiał być doskonałym taktykiem i posiadać wszystkie cechy znakomitego wodza i to było zrozumiałe samo przez się. Szczegóły taktyczne można było jednak odłożyć na dalszy plan. Widać wyraźnie, że nie to było przedmiotem zainteresowania audytorium Merobaudesa, a w sztuce komponowania panegiryków przez ponad 100 lat zaszły znaczne zmiany. W utworach VI w. zagadnienia te zostały już zupełnie zmarginalizowane.

Działania wojenne to nie tylko bitwy i taktyka. Dobry dowódca nie może zaniedbywać logistyki, kwatermistrzostwa i innych powiązanych z nimi spraw. Teodozjusz przygotowując się do wojny z uzurpatorem Maksymusem najpierw zabezpieczył swoją wschodnią flankę przy pomocy systemu sojuszy, a następnie podzielił armię na trzy części. Miało to stworzyć wrażenie, że jego wojska są liczniejsze niż w rzeczywistości i uniemożliwić przeciwnikowi ewentualną ucieczkę ${ }^{60}$. Podobnie Konstancjusz (Chlorus) przed wyruszeniem do Brytanii zabezpieczył najpierw granicę na Renie ${ }^{61}$. Kiedy już rozpoczną się działania wojenne dobry wódz winien wykonać szereg czynności przygotowawczych, aby zbliżające się starcie zbrojne odbyło się w sprzyjających okolicznościach. Działalność ta była różnorodna. Teodozjusz wybierał właściwe miejsce do bitwy (locum bello antecapere), wychodził na zwiady (speculatum egredi),

${ }^{58}$ Por. odpowiednio: Panegyricus dictus Constantino Filio Constantii 6, 3, ed. Mynors, s. 597; Panegyricus Nazarii dictus Constantino 24, 1, ed. Mynors, s. 619 (Turyn) oraz Panegyricus dictus Constantino Filio Constantii 8, 3, ed. Mynors, s. 598; Panegyricus Nazarii dictus Constantino 25, 3nn, ed. Mynors, s. 620nn (Werona).

${ }^{59}$ Por. Merobaudes, (Panegyricus I) frg. II B, 11-24, MGH Auctores Antiquissimi XIV 10, thum. Szopa, s. 220.

${ }^{60}$ Por. Panegyricus latini Pacati Drepani dictus Theodosio 32, 1nn, ed. Mynors, s. 664nn. Autor pisze nawet, że przygotowywał się on jak do wojny z Perseuszem (ok. 213 - ok. 165 prz. Chr.), Pyrrusem (ok. 318-272 prz. Chr.) albo samym Hannibalem (ok. 247-183 prz. Chr.).

${ }^{61}$ Por. Panegyricus Constantio Caesari dictus 13, 3, ed. Mynors, s. 549. 
wymierzał obóz (castra metari) ${ }^{62}$. Aecjusz analizował topografię miast (situs urbium), odmierzał górskie wąwozy, czy bezkresne pola (angustias montium aut vasta camporum), sprawdzał przeprawy rzeczne (fluminum transitus) oraz długość i szerokość dróg (viarum spatia) ${ }^{63}$. Ponadto wyszukiwał miejsca najstosowniejsze dla przemarszu jazdy i piechoty (quis pediti, quis / equiti accomodatior locus), zdatniejsze do natarcia (excursui aptior) i bezpieczniejsze do odwrotu (receptui tutior) ${ }^{64}$. Merobaudes podsumowuje wszystkie starania Aecjusza stwierdzeniem, że dzięki temu:

„zdobywasz przewagę na wojnie, nawet gdy trwa przerwa w zmaganiach”65.

Wszystkie te czynności świadczą o dużej roztropności (prudentia), która jest niezbędna do skutecznego prowadzenia działań wojennych. Każdy wódz odznaczał się przy tym całą paletą różnorodnych przymiotów od gorliwości (alacritas) po surowość (severitas). Wiele z nich, nawet przeciwstawnych, mogło być wykorzystanych podczas walki. Klasycznym przykładem może być tutaj antyteza surowości (severitas) oraz łagodności (clementia). Odpowiednio wykorzystane - zarówno przez panegirystę, jak i wychwalaną postać - mogą przyczynić się do osiagnięcia sukcesu ${ }^{66}$.

Jednak nawet najznakomitsze dowodzenie nie wystarczałoby, gdyby wódz nie dysponował odpowiednim wojskiem. Starożytni słusznie uważali, że nie w liczebności tkwiła jego największa siła, ale w jakości żołnierzy i lojalności wobec dowódcy ${ }^{67}$. Podejmowano szereg kroków, aby zapewnić te cechy armii. Jednym z najskuteczniejszych był osobisty przykład. Doskonały wódz

${ }^{62}$ Por. Panegyricus latini Pacati Drepani dictus Theodosio 10, 3, ed. Mynors, s. 634.

${ }^{63}$ Por. Merobaudes, (Panegyricus I) frg. I B, 3-5, MGH Auctores Antiquissimi XIV 8, thum. Szopa, s. 218.

${ }^{64}$ Por. tamże 5-8, MGH Auctores Antiquissimi XIV 8, tłum. Szopa, s. 218.

${ }^{65}$ Tamże 8-9, MGH Auctores Antiquissimi XIV 8: „ita ad bellum proficit etiam ipsa in- / tercaped $>_{0}$ bellorum", thum. Szopa, s. 218. Por. Panegyricus dictus Constantino Filio Constantii 22, 1, ed. Mynors, s. 605: „Quisnam iste est tam continuus ardor? Quae divinitas perpetuo vigens motu? Omnium rerum intervalla sunt: cessat terra novalibus, dicuntur interdum flumina resistee, sol ipse noctibus adquescit. Tu, Constantine, solus infatigabilis bellis bella continuas, victorias victoriis cumulas".

${ }^{66}$ Por. Panegyricus Constantino Augusto dictus 10, 3-4, ed. Mynors, s. 577: „Tuta clementia est quae parcit inimicis et sibi magis prospicit quam ignoscit; te vero, Constantine, quantumlibet oderint hostes, dum perhorrescant. Haec est enim vera virtus, ut non ament et quiescant”, thum. własne: „Łaskawość zapewnia bezpieczeństwo wówczas, kiedy oszczędza wrogów i raczej zabezpiecza swoją przyszłą korzyść niż tylko wybacza im. Ciebie bowiem Konstantynie, tak bardzo nienawidzą wrogowie, jak bardzo się boją. To bowiem prawdziwe męstwo, aby nie kochali, ale bali się". Wraz z rozwojem gatunku clementia staje się cnotą nadrzędną. Por. Priscianus, De Laude Anastasii Imperatoris 67-79, ed. Coyne, s. 50-51.

${ }^{67}$ Por. Panegyricus dictus Constantino Filio Constantii 2, 6 - 5, 5, ed. Mynors, s. 595-597, gdzie autor kilkakrotnie omawia kwestię znaczenia liczebności żołnierzy podczas kampanii posiłkując się przykładami z przeszłości. 
dzielił trudy ze swoimi żołnierzami. Razem z nimi sypał wały, stawał na warcie, ,pancerz jest dla niego raczej strojem niż ochroną”, a „łożem jest mu naga skała" ${ }^{\circ}$. Godny przytoczenia w tym miejscu jest fragment z panegiryku Sydoniusza Apolinarego dla cesarza Majoriana (ok. 420 - 7 VIII 461; cesarz od 1 IV 457). Autor ten przedstawił zimowy pochód przez Alpy, a na czele kroczącego w skrajnie trudnych warunkach oddziału umieścił samego cesarza. Jeden z żołnierzy barbarzyńskiego pochodzenia pytająco wzdycha:

„z jakiego on plemienia, jeżeli ja, Scyta,

nie dorównuję mu wytrzymałością?"69.

Władca nie tylko znosi to samo, co żołnierze, lecz karci narzekających i podnosi na duchu upadłych. Ta sama postawa winna go cechować podczas bitwy, kiedy to dowódca walczy w jednym szeregu ze swoimi ludźmi. Niezwykle plastycznie zobrazował to autor panegiryku dla cesarza Maksymiana. W wykreowanym przez niego obrazie władca dwoi się i troi na polu bitwy przepływając między oddziałami niczym wezbrana po wiosennych roztopach rzeka $^{70}$. Oczywiście, czasem takie osobiste męstwo wiązało się z dużym ryzykiem. $Z$ tego powodu niektórzy panegiryści ganili je otwarcie. Anonimowy autor panegiryku dla cesarza Konstantyna w rozbudowanym fragmencie krytykuje postawę władcy argumentując, że to czego wymaga się od wodza, nie jest tożsamym z oczekiwaniami wobec cesarza ${ }^{71}$. Strach o bezpieczeństwo władcy jest większy niż ewentualna radość ze zwycięstwa. Czytając ten fragment można odnieść wrażenie, że panegirysta wręcz strofuje panującego. Nie dajmy się jednak zwieść. Jest to tylko kolejny środek mający wzbudzić podziw dla wychwalanej osoby, a komunikat, który trafiał do odbiorcy, był jasny: władca osobistym przykładem męstwa zagrzewa do walki swoich żołnierzy. Wykreowana postawa była z pewnością pożądaną w środowiskach wojskowych i mogła pozytywnie wpływać na morale. Ten sam efekt starano się uzyskiwać zapewniając o miłości jaka wiązała wodza z jego oddziałami. Dobry dowódca kochał swoich żołnierzy, a oni kochali jego. Potwierdza to Nazariusz w panegiryku dla Konstantyna zapewniając, że w ten (znakomity) sposób wojsko może prowadzić jedynie moc nieba albo miłość wodza ${ }^{72}$. Nieco

${ }^{68}$ Por. Panegyricus latini Pacati Drepani dictus Theodosio 10, 3, ed. Mynors, s. 653-653: trwanie w pierwszej linii (stare pro signis), warta według losowania (excubias sorte agere), wznoszenie wału (vallum ferre), bycie „,wodzem w radzie a żołnierzem w przykładzie (dux esse consilio miles exemplo)" oraz Merobaudes, (Panegyricus I) frg. 1 A, 15-18, MGH Auctores Antiquissimi XIV 7: „Tibi enim cubil<e nuda rupes” oraz „lorica non tam munimen quam vestimentum”, thum. Szopa, Flavius Merobaudes, s. 217.

${ }^{69}$ Por. Sidonius Apollinaris, Carmen V 529-530, ed. Anderson, s. 106: „qua dicam gente creatum quem Scytha non patior?", thum. Borożek, s. 239.

${ }^{70}$ Por. Mamertini (?) Panegyricus Maximiano Augusto dictus 5, 3, ed. Mynors, s. 526.

${ }^{71}$ Por. Panegyricus dictus Constantino Filio Constantii 9, 4-6, ed. Mynors, s. 599.

${ }^{72}$ Por. Panegyricus Nazarii dictus Constantino 7, 4, ed. Mynors, s. 612. 
dalej szerzej opisuje on te kwestie podsumowując całość stwierdzeniem, że: „miłość [do] wodza czyni żołnierza mężniejszym”73. Owa miłość połączona jest z przeświadczeniem, że prowadzona armia jest znakomita i dowódca nie ma co do tego żadnych wątpliwości ${ }^{74}$.

Pomimo wszystkich wyżej wymienionych cech, które połączone w jednej osobie kreowały idealnego wodza, starożytni żywili przekonanie, że niezbędny jest jeszcze czynnik nadnaturalny - szczęście wojenne. W zależności od światopoglądu wychwalanej postaci oraz preferencji panegirysty była to Fortuna lub Opatrzność Boża. Dowódcę winna więc cechować felicitas oraz pietas $^{75}$. Pacatus w panegiryku na cześć cesarza Teodozjusza wyraża wielce znamienną opinię, że dwa czynniki winny cechować sławnego wodza, największe męstwo oraz powodzenie ${ }^{76}$. Ten sam autor szerzej traktuje te kwestie bardzo ciekawie przedstawiając swoje rozważania. Oto otrzymujemy upersonifikowany obraz cnót wodza, które uznając się za autorki wszelakich sukcesów, spierają się na ten temat z Fortuną ${ }^{77}$. Obie strony przedstawiają swoje zasługi, a autor sytuuje się w roli bezstronnego obserwatora. Celem passusu jest nie tylko egzemplifikacja pozytywnych cech władcy, lecz również wyrażenie przekonania o pomocy niebios, którą ten otrzymuje. W panegirykach z VI w., zwłaszcza napisanych na Wschodzie, czynnik ten zaczyna wyraźnie dominować nad typowo ludzkimi zaletami. Władca odnosi sukcesy wojenne dlatego, że jest pobożny, a Opatrzność Boża czuwa nad nim. Pryscjan w swoim panegiryku dla cesarza Anastazjusza nie pozostawia wątpliwości co do tego, komu panujący zawdzięcza swe sukcesy wojenne. Już na samym początku panegiryku informuje zarówno publiczność, jak i samego władcę, że to Boża Moc zapewnia wszelką pomyślność, zarówno w czasie pokoju, jak i podczas wojny $^{78}$. Motyw ten pojawia się wielokrotnie w samym utworze i można go uznać za przewodni ${ }^{79}$. Jako namaszczony przez Boga Anastazjusz wspierany jest „prawicą Boską” (dextera Dei) i już sam ten fakt gwarantuje mu sukcesy $^{80}$. Podobnie Korippus wychwalając Justyna II (ok. 520 - 5 X 578; cesarz od

${ }^{73}$ Por. tamże 19, 4, ed. Mynors, s. 618: „amor principis facit militem fortiorem”, tłum. własne.

${ }^{74}$ Panegirysta przedstawia audytorium żołnierzy niczym herosów zesłanych z niebios. Por. tamże 14, 3, ed. Mynors, s. 615): ,illi caelo lapsi, illi divinitus missi gloriabantur, quod tibi militabant”.

${ }^{75}$ Te dwie cechy zostały szczególnie podkreślone np. w [Mamertini] Magistri †Memet Genethliacus Maximiani Augusti (ed. R.A.B. Mynors, w: In Praise of Later Roman Emperors, s. 532-542) jednak pozostałe utwory też nie są ich pozbawione.

${ }^{76}$ Por. Panegyricus latini Pacati Drepani dictus Theodosio 6, 1, ed. Mynors, s. 650: „,nam cum duo sint quae claros duces faciant, summa virtus summaque felicitas".

${ }^{77}$ Por. tamże 41-42, ed. Mynors, s. 670-671.

${ }^{78}$ Por. Priscianus, De laude Anastasii Imperatoris 4-7, ed. Coyne, s. 49.

${ }^{79}$ Por. tamże, ad indicem.

${ }^{80}$ Motyw „bożej prawicy” pojawia się trzykrotnie i to w różnych kontekstach. Z punktu widzenia niniejszych rozważań najciekawsze jest drugie wystapienie gdzie summi genitoris dextera powala walczących Izauryjczyków określonych tu jako iniusti, por. tamże 99-103, ed. Coyne, s. 51: 
15 XI 565) uznaje znaczenie nadprzyrodzonego wsparcie. Wrogie cesarstwu ludy Getów, Franków, Longobardów i Gepidów pobiła samodzielnie domini fortuna, zapewniając jego wojsku całkowite bezpieczeństwo ${ }^{81}$. Wszystko to, a także wyniesienie na tron cesarski, zawdzięcza on Bogu, określonemu tutaj jako pater omnipotens ${ }^{82}$. W efekcie, w obu tych panegirykach, najważniejsza cechą cesarza nie jest już szeroko rozumiana dzielność (w jej różnorodnych aspektach), ale pobożność, od której zależy wszelkie powodzenie.

Zgodnie z obowiązującymi regułami retorycznymi, budując wizerunek idealnego wodza, ówcześni twórcy korzystali z różnorodnych środków stylistycznych. Jednym z nich, który warto skomentować nieco obszerniej w kon-

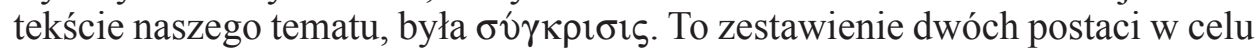
podkreślenia wyższości jednej z nich było tradycyjnym środkiem wykorzystywanym przez panegirystów $\mathrm{w}$ różnych partiach dzieła, a szczególnie podczas budowania wizerunku doskonałego dowódcy. Współczesnych adresatów porównywali twórcy pochwały z wybitnymi postaciami historycznymi. Analiza utworów pokazuje, że można tu mówić o pewnym kanonie. Jeżeli chodzi o wybitne indywidualności z historii rzymskiej, to na plan pierwszy wysuwa się zdecydowanie Juliusz Cezar. On i jego czyny były powszechnie znane i szanowane, co czyniło wszelkie zestawienia bardzo sugestywnymi. Merobaudes w swoim II Panegiryku wychwalającym działania Aecjusza w Galii obszernie porównuje je z wcześniejszymi dokonaniami Cezara. Z oczywistych względów konfrontacja wypada korzystnie dla adresata panegiryku. Pierwsza jej zapowiedź znajduje się już na początku utworu (ww. 11-12), jednak prawdziwe jej rozwinięcie umieszczone zostało dalej. Dowiadujemy się zatem, że co prawda jeden i drugi wódz pokonał przeciwnika, ale Juliusz Cezar walczył wówczas, kiedy Rzym był u szczytu swojego rozkwitu, wojsko zaś, które prowadził, było liczne, a wróg nieobeznany w wojnie. Mimo to, zmagania trwały aż 10 lat, a sam wódz wrócił do Rzymu już jako dojrzały człowiek ${ }^{83}$. Wyzwania stojące przed Aecjuszem były znacznie poważniejsze. Barbarzyńcy już okrzepli, połączyli się sojuszem przeciwko Rzymowi i oczekiwali na legionistów za umocnieniami ${ }^{84}$. Ponieważ wódz przezwyciężył wszystkie te przeciwności, skala jego dokonań jest znacznie większa niż sławnego poprzednika. Drugim obok Cezara wodzem, który na stałe trafił do kanonu porównań panegirystów,

\footnotetext{
„Nam quos non valuit robur corrumpere Martis / Nec tot ductorum circumdata moenia vallo, / Deiicit hos summi genitoris dextera flagrans/Iniustos contra praesenti numine pugnans".

${ }^{81}$ Por. Corippus, In laudem Iustini, Praefatio 10-15, ed. A. Cameron: Flavius Cresconius Corippus, In laudem Iustini Augusti minoris (in praise of Justin II), London 1976, 85.

${ }^{82}$ Por. tamże 19-20, ed. Cameron, s. 85: ,solum excellentem conscendere iussit in arcem / te pater omnipotens, summaque in sede locavit".

${ }^{83}$ Por. Merobaudes, (Panegyricus II) 144-148, MGH Auctores Antiquissimi XIV 17, thum. Szopa, s. 226. Por. też A. Bruzzone, Flavio Merobaude. Panegirico in Versi, Roma 1999, 222-230.

${ }^{84}$ Por. Merobaudes, (Panegyricus II) 148-157, MGH Auctores Antiquissimi XIV 17, thum. Szopa, s. 226.
} 
był Aleksander Wielki (20/21 VII 356 - 10/11 VI 323 prz. Chr.; król od 336) $)^{85}$. Pomimo znacznego dystansu czasowego, gwiazda sławnego Macedończyka nie straciła nic ze swojego blasku i mimo sporych zmian kulturowych, również ewolucji w strukturze samych panegiryków, pojawiała się nieprzerwanie nawet $\mathrm{w}$ najpóźniejszych, analizowanych w niniejszym artykule utworach. W Ennodiuszowym panegiryku na cześć króla Teodoryka znajduje się obszer-

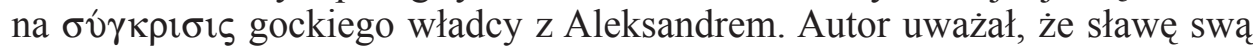
zawdzięczał Macedończyk nie tyle niezwykłym czynom, lecz raczej pomocy retorów, którzy przez wieki rozsławili jego osobę ${ }^{86}$. W przeciwieństwie do poprzednika, król Teodoryk samymi czynami zdobył nieśmiertelną sławę, a literackie hiperbole pochlebców nie są mu potrzebne. Jego dokonania są większe niż osiągnięcia starożytnych, pomimo że te ostatnie zostały przejaskrawione wieloma kłamstwami ${ }^{87}$. Aleksander pojawia się również w innych utworach zarówno jako indywidualny protagonista, jak i jako element egzemplifikacji. W panegiryku Pacatusa na cześć cesarza Teodozjusza, władca zostaje zestawiony równocześnie z Aleksandrem, Scypionem Afrykańskim (236-183 prz. Chr.) oraz Hannibalem (ok. 247-183 prz. Chr.) ${ }^{88}$. W klasycznym kanonie porównań znajdywali się również Publiusz Decjusz Mus (†340 prz. Chr.), ród Fabiuszy, Mariusz (157 - 13 I 86 prz. Chr.), Pompejusz Wielki (29 IX 106 - 28 IX 48 prz. Chr.), Marek Antoniusz (14 I 83 - 1 VIII 30 prz. Chr.), August (23 IX 63 prz. Chr. - 19 VIII 14 po Chr.; cesarz od 16 I 27 prz. Chr.), Klaudiusz (1 VIII 10 prz. Chr. - 13 X 54 po Chr.; cesarz od 25 I 41) oraz Trajan (18 IX 53 - 8/9 VIII 117; cesarz od 27/28 I 98). W poszczególnych utworach można odnaleźć pojedyncze nawiązania do innych postaci historycznych, ale wyżej wymienieni z pewnością wiedli prym. Na tej podstawie możemy powiedzieć niemało na temat kanonu edukacji w interesującym nas okresie, co jednak zbyt daleko odbiegałoby od tematu niniejszych rozważań.

$$
* * *
$$

Podsumowując należy stwierdzić, że kreując obraz idealnego wodza stanowiły panegiryki ważny element autoprezentacji opiewanej osoby, którą najczęściej był władca, ale też czasami jeden z jego najbliższych współpracowników (z reguły magister militum). Odpowiedni wizerunek panującego wpływał na jego wizerunek zarówno w społeczeństwie, jak i w armii, co miało fundamentalne znacznie dla stabilności rządów. Wraz z upływem czasu, rosła

\footnotetext{
${ }^{85}$ Wykaz licznych porównań do tej postaci zarówno w panegirykach łacińskich, jak i greckich, por. Portmann, Geschichte in der Spätantiken Panegiryk, s. 329-330.

${ }^{86}$ Por. Ennodius, Panegyricus 78, ed. Ch. Rohr: Der Theoderich-Panegyricus des Ennodius. Überlieferungs- und Wirkungsgeschichte - Allgemeine Einführung - Edition - Übersetzung Erläuterungen, Wien 1994, 293.

${ }^{87}$ Por. tamże: „minora sunt eius veris actibus, quamvis aucta sint veterum gesta mendaciis”.

${ }^{88}$ Por. Panegyricus latini Pacati Drepani dictus Theodosio 8, 4, ed. Mynors, s. 651.
} 
rola panegiryków jako elementu coraz bardziej rozbudowanego ceremoniału dworskiego. Co więcej, same utwory zaczęły opisywać wydarzenia, w których centrum się znajdywały. Obserwując wizerunek wodza doskonałego przedstawianego w panegirykach można bardzo wyraźnie zaobserwować ewolucję tego gatunku w omawianym okresie. Droga którą przeszedł, od narracyjnych panegiryków epoki tetrarchii, przez „,panegiryczne eposy” Klaudiana, czy Merobaudesa, aż po szczegółowy opis ceremoniału, który wysuwał się na plan pierwszy u Korippusa, znakomicie odzwierciedla szersze zmiany jakie zaszły $\mathrm{w}$ cesarstwie zarówno w aspekcie czasowym, jak i geograficznym. Z kolei elementy wspólne, dające się zaobserwować w utworze Ennodiusza, biskupa Ticinum, pokazują, że pewne tradycyjne motywy zachowały swą żywotność oraz atrakcyjność i stanowiły wielki wkład w kształtowanie kultury ostrogockiej Italii VI stulecia. Warty podkreślenia jest również wpływ chrześcijaństwa na omawiane utwory, którego analiza mogłaby być tematem na osobne studium. $\mathrm{O}$ ile do pewnego momentu panegiryki korzystały z języka charakterystycznego dla klasycznej spuścizny Grecji i Rzymu czasów dawniejszych, mimo że były pisane przez chrześcijańskich autorów dla chrześcijańskich władców, o tyle z czasem można zaobserwować stopniowy zanik pewnych motywów pogańskich i pojawianie się w ich miejsce elementów chrześcijańskich. Doskonale może zobrazować tę tezę różnica pomiędzy panegirykami biskupa Augustunometum Sydoniusza Apolinarego a biskupa Ticinum, Ennodiusza, między którymi dystans czasowy nie był przecież aż tak znaczny. Na końcu można, nieco przewrotnie, zapytać: czy wódz doskonały łacińskiego panegiryku wygrałby bitwę? Odpowiedź musi być twierdząca. Autorzy panegiryków, pomimo pompatyczności z jaką to robili, starali się stworzyć spójny wizerunek skutecznego dowódcy. Ich wiedza była prawdopodobnie dość powierzchowna, ale wykreowany dowódca godzien był zaufania a odbiorcy mogli oczekiwać, że pod jego komendą armia rzymska obroni państwo i będzie kroczyć od sukcesu do sukcesu ${ }^{89}$. Niestety, rzeczywistość niejednokrotnie znacznie odbiegała od tego idealnego obrazu.

\footnotetext{
${ }^{89}$ Jedynie Flawiusz Merobaudes był z pewnością obeznany z rzemiosłem wojennym zarówno w teorii jak i praktyce. Służąc pod komendą Aecjusza doszedł do rangi magistra militum a jego skuteczność bojowa jest potwierdzona źródłowo, por. Flavius Merobaudes, [Opera], a translation and historical commentary by F.M. Clover, Transactions of the American Philosophical Society N.S. 61/1, Philadelphia 1971, 9-10; Szopa, Flavius Merobaudes, s. 33-68. Por. też Wilczyński, Germanie w stużbie zachodniorzymskiej, s. 247-249. Na temat pozostałych twórców trudno wyrokować. Ciekawym zabiegiem mogłoby być zestawienie przedstawionego wizerunku ze specjalistycznymi traktatami wojskowymi, w których autorzy informowali czytelnika, jakimi cechami powinien odznaczać się idealny dowódca, zob. Greek and Roman Military Writers. Selected Readings, ed. B. Campbell, London - New York 2004, 53-87.
} 
THE PERFECT GENERAL

ACCORDING TO THE LATE ROMAN LATIN PANEGYRICS

(Summary)

In this article I am describing how Roman panegyric's writers of Late Antiquity (XII Panegyrici Latini, Claudius Claudianus, Sidonius Apollinaris, Flavius Merobaudes, Priscian, Ennodius, Corippus and others) presented an image of the perfect general with reference to their object of praise. On the ground of detailed analysis of those features I am going to indicate the most expected ones according to the social reception. Moreover, I will point out those means which were used by the authors to create the image of the ideal general. Next, I will pay attention to how the authors change their way in presenting the perfect general and how this development was connected with the general evolution of the genre. Lastly, I will answer a quite perverse question: if the perfect general could lead his soldiers to a victory in a real battle. In the background there will be a continuous question, if the panegyric - despite its limitation - can or can't be treated as a valuable historical source.

Key words: perfect general, Late Antiquity, latin panegyric, propaganda, autopresentation.

Słowa kluczowe: wódz idealny, późny antyk, panegiryk łaciński, propaganda, autoprezentacja władcy. 
